\title{
Influence of non-genetic factors on the maternal ability of Santa Inês ewes
}

\author{
Tatiana Saraiva Torres ${ }^{1,2}$ Luciano Silva Sena ${ }^{2}$ Alan Oliveira do Ó$^{3} \mathbb{D}$ \\ Gleyson Vieira dos Santos ${ }^{2,4}$ Artur Oliveira Rocha ${ }^{5}$ José Lindenberg Rocha Sarmento ${ }^{6^{*}}$ D
}

${ }^{1}$ Universidade Estadual de Goiás (UEG), Campos Belos, GO, Brasil.

${ }^{2}$ Zootecnista, Doutor(a) em Ciência Animal, Universidade Federal do Piauí (UFPI), Teresina, PI, Brasil.

${ }^{3}$ Instituto Federal de Educação, Ciência e Tecnologia do Piauí (IFPI), Corrente, PI, Brasil.

${ }^{4}$ Universidade Federal do Piauí, Campus Professora Cinobelina Elvas, Bom Jesus, PI, Brasil.

${ }^{5}$ Graduação em Medicina Veterinária, Universidade Federal do Piauí (UFPI), Teresina, PI, Brasil.

${ }^{6}$ Departamento de Zootecnia (DZO), Universidade Federal do Piauí (UFPI), 64049-550, Teresina, PI, Brasil. E-mail: sarmento@ufpi.edu.br.

${ }^{*}$ Corresponding author.

ABSTRACT: The aim of this study was to evaluate the influence of different non-genetic effects on indicator traits for maternal ability in Santa Inês ewes. Data included performance records of 100 lambs (males and females) born from 59 dams, from 2009 to 2012. The analyzed traits were birth weight $(B W)$, weaning weight $(W W)$, average daily gain from birth until weaning (ADGBW), total litter weight at birth (TLWB), and total litter weight at weaning (TLWW). The effects analyzed were the year of birth of the lamb, birth season, dam age at lambing, dam weight at lambing, sex of the lamb, lamb birth type, interaction between sex and birth type, and interaction between sex and birth season. SAS ${ }_{\circledR}$ software (SAS University Edition, USA) was used for calculation of the analysis of variance, means, and Pearson correlation coefficients. With the exception of the birth season, all the other environmental effects evaluated had a significant influence on at least one of the studied traits. The correlation estimates ranged from low to high and were either positive or negative. Birth weight was negatively correlated with the birth type and influenced positively all the other performance traits evaluated. The maternal ability of Santa Inês ewes was more clearly influenced by the age and weight of the dam at lambing, and the lamb birth type.

Key words: birth type, hair sheep, lamb performance, meat production, weaning weight.

Influência de fatores não-genéticos na habilidade materna de ovelhas Santa Inês

RESUMO: $O$ objetivo deste estudo foi avaliar a influência de diferentes efeitos não-genéticos sobre características indicadoras de habilidade materna em ovelhas da raça Santa Inês. Os dados utilizados incluíram registros de desempenho de 100 cordeiros (machos e fêmeas) filhos de 59 ovelhas, nascidos de 2009 a 2012. As características analisadas foram peso ao nascimento (PN), peso ao desmame (PD), ganho médio diário do nascimento ao desmame (GMND), peso total das crias ao nascer (PTCN) e peso total das crias ao desmame (PTCD). Os efeitos analisados foram ano de nascimento da cria, estação de nascimento, idade da mãe ao parto, peso da mãe ao parto, sexo da cria, tipo de nascimento da cria, interação entre sexo e tipo de nascimento, e interação entre sexo e estação de nascimento. O programa SAS (SAS University Edition, EUA) foi utilizado para o cálculo de análise de variância, médias e coeficientes de correlação de Pearson. Com exceção da estação de nascimento, os demais efeitos avaliados exerceram influência significativa sobre pelo menos uma das características estudadas. As estimativas de correlação variaram de baixa a alta magnitude e foram tanto positivas quanto negativas. O peso da cria ao nascimento foi negativamente correlacionado com o tipo de nascimento e influenciou positivamente todas as outras caracteristicas de desempenho avaliadas. A habilidade materna de ovelhas Santa Inês foi mais claramente influenciada pela idade e peso da mãe ao parto e pelo tipo de nascimento da cria.

Palavras-chave: desempenho de cordeiros, ovinos deslanados, peso ao desmame, produção de carne, tipo de nascimento.

\section{INTRODUCTION}

Sheep farming is responsible for $4.6 \%$ of the world's meat production (FAO, 2019). In Brazil, the sheep flock is composed of almost 18 million animals, of which $64.0 \%$ are concentrated in the Northeast region (IBGE, 2018). In this region, most of the ovine flocks are composed of woolless sheep. These animals are well-adapted to tropical climate conditions and are able to express their production potential in harsh environments (MCMANUS et al., 2010).

Sheep growth from birth until weaning is determined by the genes of the animal, the maternal genetic composition, the environment where the lamb is reared, and the environment provided by the dam, that is, maternal care and milk supply (SARMENTO et al., 2011; DWYER, 2014). Thus, it is relevant to measure which environmental effects (i.e., non-genetic factors) 
may affect the characteristics that are indicative of maternal ability, which are measured based on the lamb performance from birth until weaning.

Part of the maternal ability is considered as an environmental effect that influences the growth and development of the offspring (GOWANE et al., 2014). Therefore, the models used to estimate the direct additive genetic parameters must also capture this source of variation, otherwise, the estimates may be biased (EL-AWADY, 2011).

Some of the main environmental factors that affect the body development of lambs are the year, month, and type of birth, gender, and age and weight of the dam at lambing (BAHREINI BEHZADI et al., 2007). The period of birth of the lamb may directly affect food availability (i.e., milk production of the dam) and the incidence of diseases. The type of birth and gender of the offspring may significantly influence birth weight and postnatal development because increasing litter size reduces individual birth weight, and males are usually heavier than females (GARDNER et al., 2007). Regarding the dam age at lambing, lambs born to ewe lambs are usually smaller and lighter than those born to mature ewes (PETTIGREW et al., 2019). Maternal weight also has a significant effect on lamb birth weight, as heavier dams are usually well nourished and tend to give birth to heavier lambs (KORITIAKI et al., 2013).

Due to the importance of the Santa Inês breed in Brazilian sheep farming, especially in the Northeastern semi-arid region, it is important to identify the environmental factors that affect the maternal ability of ewes of this breed to improve the statistical models used in genetic evaluations. Thus, the objective of this study was to evaluate the influence of the birth year of the lamb, birth season, dam age at lambing, dam weight at lambing, sex of the lamb, and lamb birth type on maternal ability indicator traits in ewes of the Santa Inês breed.

\section{MATERIALS AND METHODS}

\section{Experiment location and flock management}

The experiment was conducted at the Nucleus for Selection and Conservation of Hair Sheep Genetic Resources of the Campus Professora Cinobelina Elvas of the Federal University of Piauí (UFPI), located in the municipality of Bom Jesus, Piauí, Brazil (latitude 9॰04'57.8'S, longitude $44^{\circ} 19^{\prime} 36.8^{\prime \prime} \mathrm{W}$ at an altitude of $277 \mathrm{~m}$ a.s.l.), from September 2008 to December 2012. The climate of Bom Jesus is tropical with seasonal winter drought, with an annual mean temperature of $27.3{ }^{\circ} \mathrm{C}$, ranging from $26.3^{\circ} \mathrm{C}$ (January) to $28.8^{\circ} \mathrm{C}$ (September), pluvial indexes ranging from $1.5 \mathrm{~mm}$ (August) to $174.1 \mathrm{~mm}$ (January), and an annual total precipitation of 984.8 $\mathrm{mm}$ (MEDEIROS, 2019). According to INMET (2020), the average air temperature $\left({ }^{\circ} \mathrm{C}\right)$, relative humidity of the air $(\%)$, and annual precipitation ( $\mathrm{mm})$ in Bom Jesus, from 2008 to 2012, were, respectively: $26.29^{\circ} \mathrm{C}, 63.46 \%$, and $3,079.8 \mathrm{~mm}$ in $2008,26.52^{\circ} \mathrm{C}$, $66.84 \%$, and $886.4 \mathrm{~mm}$ in $2009,27.90{ }^{\circ} \mathrm{C}, 55.05 \%$, and $540.8 \mathrm{~mm}$ in $2010,26.24{ }^{\circ} \mathrm{C}, 65.17 \%$, and $1092.6 \mathrm{~mm}$ in 2011 , and $27.61^{\circ} \mathrm{C}, 58.04 \%$, and $509 \mathrm{~mm}$ in 2012 .

The sheep raised at the experimental site, totalling 59 females and 100 males, were divided into two groups based on their categories: maternity (pregnant ewes, lambing ewes, and their offspring), and unmated animals (non-pregnant ewes, wethers, and other males in non-reproductive phase). The breeding males were kept in separate pens throughout the year, receiving feed in the trough, whereas the other animals had access to cultivated Andropogon gayanus Kunth cv. Planaltina (CIAT621), Tifton-85 (Cynodon dactylon), and native pastures, specifically during the rainy season (November to May).

During food shortage (dry season, i.e., June to October), the diet of the animals was restricted to food supplementation composed of chopped elephant grass (Pennisetum purpureum Schum. cv. Napier), leucaena hay (Leucaena leucocephala (Lam.) de Wit), corn silage (Zea mays), and concentrated rations, with a roughage: concentrate ratio of 60:40 (corn:soybean).

The lambs were kept with their dams in a maternity pen from birth until weaning (at 56 days of age), receiving concentrated rations. At the beginning of 2010, the lambs started to have free access to creep feeding during the pre-weaning period. Water and mineral salt were supplied ad libitum for all animals reared at the experiment location.

Health management included vaccinations, deworming, and clinical treatment of caseous lymphadenitis. Deworming was conducted based on the needs of the flock, generally during the rainy season due to the greater humidity.

During the breeding season, the following information was collected: the identification of breeding ewes and rams; date of service (i.e., the mating of a female with a male); and ewe weight at mating. Natural controlled mating was implemented throughout the year. The breeding rams had contact with the ewes periodically for estrus detection.

\section{Studied traits}

Weight records were collected from Santa Inês lambs every 15 days, from birth until weaning 
(at 56 days of age), during the morning shift after the animals had followed a 12-hour solid fast. All lambs were weighed individually using a clock-type scale (100 kg capacity with $400 \mathrm{~g}$ precision). Weight records collected from individuals with information on birth date, sex, birth type (single or twin), birth weight $(\mathrm{kg})$, and weaning weight $(\mathrm{kg})$ were used for the analyses. It is important to mention that some lambs died before weaning, which is why only the birth weight information of some of these animals was used.

The characteristics that were analyzed to assess the maternal ability of the ewes were as follows: lamb weight at birth (BW, $\mathrm{n}=100)$, taken individually within 24 hours of birth when the lambs were also identified with their dams, as described by CLOETE et al. (2009); lamb weight at weaning (WW, $\mathrm{n}=79$ ), recorded at 56 days of age (FREITAS et al., 2005); average daily weight gain from birth until weaning (ADGBW, $n=79$ ), calculated as the average daily weight gain of each lamb from birth until weaning, as described by FREITAS et al. (2005); total litter weight at birth (TLWB, $\mathrm{n}=85$ ), calculated as the sum of the birth weights of all lambs born per ewe per lambing (ROSATI et al., 2002); total litter weight at weaning (TLWW, $\mathrm{n}=67$ ), which consisted of the sum of the weights of all lambs weaned per ewe per lambing, as described by ROSATI et al. (2002). The data structure and descriptive statistics are summarized in Table 1.

\section{Evaluated effects}

The environmental effects considered in the statistical models to assess maternal ability were the birth year of the lamb (2009 to 2012), birth season (rainy (November to May) or dry (June to October)), dam age at lambing (years), dam weight at lambing $(\mathrm{kg})$, lamb sex (male or female), lamb birth type (single or twin), interaction between sex and birth type, and interaction between sex and birth season. Dams were grouped into the following classes based on their age at lambing: ewes up to two years of age (class 1 ); females $>$ two years old and $\leq$ three years of age (class 2); dams $>$ three years old and $\leq$ four years of age (class 3); ewes $>$ four years old (class 4 ). Dams were also grouped into classes based on their weight at lambing, as follows: ewes weighing $\leq 40 \mathrm{~kg}$ (class 1) and females weighing more than $40 \mathrm{~kg}$ (class 2).

\section{Statistical models}

The statistical models used for the different traits are described below:

$\mathrm{Y}_{i j k l m n o}=\mu+\mathrm{Yb}_{i}+\mathrm{Bs}_{j}+\mathrm{S}_{\mathrm{k}}+\mathrm{Bt}_{l}+\mathrm{Al}_{m}+\mathrm{Wl}_{n}+(\mathrm{S} \times \mathrm{Bt})$ ${ }_{k l}+(\mathrm{S} \times \mathrm{Bs})_{j k}+\mathrm{D}_{o}+\mathrm{e}_{i j k l m n o}$

for BW, WW, TLWB, and ADGBW, and $\mathrm{Y}_{i j k l m n o}=\mu+\mathrm{Yb}_{i}+\mathrm{Bs}_{j}+\mathrm{S}_{k}+\mathrm{Bt}_{l}+\mathrm{Al}_{m}+\mathrm{W}_{n}+(\mathrm{S} \times \mathrm{Bt})$ ${ }_{k l}+(\mathrm{S} \times \mathrm{Bs})_{j k}+\mathrm{D}_{o}+\mathrm{e}_{i j k l m n o}$

for TLWW, where $\mathrm{Y}$ is the observation of the studied trait, $\mu$ is the overall mean, $\mathrm{Yb}$ is the effect of the year of offspring birth, Bs represents the offspring birth season effect, $\mathrm{S}$ is the effect of the lamb sex, $\mathrm{Bt}$ represents the effect of lamb birth type, Al is the effect of dam age at lambing, W1 is the effect of dam weight at lambing, $\mathrm{S} \times \mathrm{Bt}$ represents the effect of the interaction between sex and lamb birth type, $\mathrm{S} \times$ Bs represents the effect of the interaction between the lamb sex and the offspring birth season, D is the random effect of dams, and $e$ is the random error associated with each observation.

The analyses were performed using the statistical software $\mathrm{SAS}^{\circledR}$, accessed through SAS virtual University Edition. The analysis of variance for the studied traits was tested using the restricted maximum likelihood estimation (REML) method with

Table 1 - Descriptive statistics for productive traits indicator of maternal ability in Santa Inês ewes.

\begin{tabular}{lcccccc}
\hline Trait & Sample size & Mean $(\mathrm{kg})$ & SD $(\mathrm{kg})$ & Minimum $(\mathrm{kg})$ & Maximum $(\mathrm{kg})$ & $\mathrm{CV}(\%)$ \\
\hline BW & 100 & 3.40 & 1.03 & 1.40 & 6.00 & 30.29 \\
WW & 79 & 10.64 & 3.27 & 4.75 & 0.02 & 18.22 \\
ADGBW & 79 & 0.13 & 0.05 & 1.40 & 0.25 & 10.50 \\
TLWB & 85 & 4.00 & 1.81 & 4.75 & 21.10 & 45.46 \\
TLWW & 67 & 12.04 & 3.41 & 28.32 \\
\hline
\end{tabular}

$\mathrm{BW}=$ birth weight; $\mathrm{WW}=$ weaning weight; $\mathrm{ADGBW}=$ average daily gain from birth until weaning; TLWB = total litter weight at birth; TLWW = total litter weight at weaning; $S D=$ standard deviation; $C V=$ coefficient of variation . 
the MIXED procedure. The estimated means were compared using Fisher's least significant difference test to check for significant differences $(<0.05)$. Pearson correlation coefficients were calculated using the CORR procedure.

\section{RESULTS AND DISCUSSION}

Some of the mean values of the studied traits (Table 1) are within the range reported for Santa Inês sheep in the literature. For instance, the average value of BW in the present study is within the range of 3 to $4 \mathrm{~kg}$ found by COSTA et al. (2012), KORITIAKI et al. (2013), SUPAKORN et al. (2013), and PERUZZI et al. (2015). On the other hand, the mean of WW was lower than the values reported in Santa Inês sheep by COSTA et al. (2012) and PERUZZI et al. (2015), which were 17.09 (weaning at 90 days of age) and $11.9 \mathrm{~kg}$ (mean weight of males weaned at 45 or 60 days of age), respectively. Considering the WW for females, our values were higher than those reported by PERUZZI et al. (2015), for lambs weaned at $45(8.9 \mathrm{~kg})$ or 60 days of age $(10.1 \mathrm{~kg})$. As can be observed in the results compared above, lambs weaned later tend to have higher WW. Nevertheless, some studies have shown that sheep can be weaned earlier (provided that there is adequate supplementation) without any prejudice to their development, and this can improve the production of the flock, as this practice allows the dams to have better recovery of their body condition post-lambing (FERNANDES et al., 2011; PERUZZI et al., 2015).

The variation in results among different studies, even within the same breed, is justified by the fact that the weights at birth and weaning are greatly influenced by different environmental effects, especially the maternal environment (KAMJOO et al., 2014), and by the management adopted on each farm. In the present study, some factors that probably influenced lamb performance were reproductive management, the supplementation of the dams before lambing, and the use of creep feeding for the lambs. The dams were kept in a maternity pen since the last third of their pregnancy, receiving supplemented feed. Therefore, there was no food competition among the pregnant or lambing ewes with the unmated animals that were kept in other pens. In addition, the use of creep feeding allowed the lambs to have access to solid food before weaning, which may have contributed to their increased weight gain.

The mean value of TLWB $(4.0 \mathrm{~kg})$ estimated in the current study (Table 1) was lower than the values reported by LOBO et al. (2012) and
AGUIRRE et al. (2017), which were 5.12 and 4.7 $\mathrm{kg}$, respectively, in Santa Inês lambs weaned at 60 days of age. The TLWW values reported in both the studies mentioned above were also higher than our finding for this trait. Both the aforementioned studies used more than 4,000 samples collected for over 10 years, which contributed to the higher occurrence of multiple births and consequently increased the litter size per dam and the mean TLWB and TLWW. The litter weight at weaning is directly influenced by the total weight of lambs at birth, which in turn is determined by the number of lambs born (ROSATI et al., 2002). TLWB and TLWW are widely used for selection in sheep, as these traits measure the overall productivity of the dam in terms of weight of lambs produced per parity (ROSATI et al., 2002; LÔBO et al., 2009). In fact, increasing the weight of the litter weaned per breeding ewe represents one of the most important economic contributions of genetics to a sheep production system (SNOWDER, 2008).

In order to achieve higher weaning weights in the lambs, the average daily gain is a major factor that must be considered. In this sense, increased lamb live weight gain until weaning can be achieved through greater changes in the ewe condition score during pregnancy (MOREL et al., 2009), which can be achieved through supplementation, as performed in the current study. With respect to ADGBW, ZUNDT et al. (2006) reported values ranging from $0.16 \pm 0.01$ to $0.18 \pm 0.01 \mathrm{~kg}$ in Santa Inês lambs weaned at 60 days of age. In a study to evaluate the effect of environmental factors on the performance of purebred and crossbred Santa Inês lambs weaned at 70 days of age, KORITIAKI et al. (2013) reported an ADGBW of $0.16 \pm 0.00 \mathrm{~kg}$, specifically for singleborn lambs. These values were higher than our finding for this trait (Table 1). However, when considering only the value of ADGBW in purebred Santa Inês lambs, KORITIAKI et al. (2013) reported the same overall mean value as that of the present study $(0.13)$. The differences among studies are in part due to the different weights and ages of the dams at lambing, as well as the different proportions of birth types, the food management adopted, and other particularities of each work, as mentioned above.

Significant differences $(\mathrm{P}<0.05)$ were observed for all the studied traits considering the effect of the birth year of lambs (Table 2). The most significant differences were observed in the year 2012 for WW, TLWW, and ADGBW. Some of the factors that most likely caused such differences among years were the annual rainfall distribution and some adjustments made to reproduction and 
Table 2 - Estimated means for the influence of different environmental effects on birth weight (BW), weaning weight (WW), total litter weight at birth (TLWB), total litter weight at weaning (TLWW), and average daily gain from birth until weaning (ADGBW) in Santa Inês sheep.

\begin{tabular}{|c|c|c|c|c|c|c|}
\hline ----------------------------E & -------------------------- & BW (kg) & WW (kg) & TLWB (kg) & $\begin{array}{l}\text { TLWW } \\
\text { (kg) }\end{array}$ & $\begin{array}{l}\text { ADGBW } \\
(\mathrm{kg})\end{array}$ \\
\hline \multirow{4}{*}{$\begin{array}{l}\text { Year of birth of the } \\
\text { lambs }\end{array}$} & 2009 & $2.80^{c}$ & $9.61^{b}$ & $4.13^{b}$ & $12.00^{\mathrm{b}}$ & $0.12^{b}$ \\
\hline & 2010 & $3.86^{\mathrm{a}}$ & $9.48^{\mathrm{b}}$ & $5.22^{\mathrm{a}}$ & $11.39^{\mathrm{b}}$ & $0.10^{\mathrm{b}}$ \\
\hline & 2011 & $3.20^{\mathrm{bc}}$ & $9.54^{\mathrm{b}}$ & $4.72^{\mathrm{b}}$ & $10.90^{\mathrm{b}}$ & $0.11^{\mathrm{b}}$ \\
\hline & 2012 & $3.60^{\mathrm{ab}}$ & $12.72^{\mathrm{a}}$ & $5.01^{\mathrm{b}}$ & $15.38^{\mathrm{a}}$ & $0.16^{\mathrm{a}}$ \\
\hline \multirow{2}{*}{ Birth season } & Rainy & 3.19 & 9.94 & 4.61 & 11.92 & 0.12 \\
\hline & Dry & 3.54 & 10.74 & 4.93 & 12.91 & 0.13 \\
\hline \multirow{4}{*}{ Dam age at lambing } & up to 2 & 3.39 & $7.90^{\mathrm{b}}$ & 4.80 & $10.01^{\mathrm{b}}$ & $0.08^{\mathrm{b}}$ \\
\hline & $>2$ and $\leq 3$ & 3.23 & $10.99^{\mathrm{a}}$ & 4.82 & $13.55^{\mathrm{a}}$ & $0.14^{\mathrm{a}}$ \\
\hline & $>3$ and $\leq 4$ & 3.19 & $10.32^{\mathrm{a}}$ & 4.73 & $13.05^{\mathrm{a}}$ & $0.13^{\mathrm{a}}$ \\
\hline & $>4$ & 3.64 & $12.13^{\mathrm{a}}$ & 4.73 & $13.07^{\mathrm{a}}$ & $0.15^{\mathrm{a}}$ \\
\hline \multirow{2}{*}{ Dam weight at lambing } & $\leq 40 \mathrm{~kg}$ & $3.17^{b}$ & 10.06 & $4.41^{\mathrm{b}}$ & 11.89 & 0.12 \\
\hline & $>40 \mathrm{~kg}$ & $3.57^{\mathrm{a}}$ & 10.61 & $5.13^{\mathrm{a}}$ & 12.95 & 0.13 \\
\hline \multirow{2}{*}{ Sex } & Male & 3.52 & 10.38 & 4.71 & $11.01^{\mathrm{b}}$ & 0.12 \\
\hline & Female & 3.21 & 10.29 & 4.83 & $13.83^{\mathrm{a}}$ & 0.13 \\
\hline \multirow{2}{*}{ Birth type } & Single & $3.55^{\mathrm{a}}$ & $12.19^{\mathrm{a}}$ & $3.61^{\mathrm{b}}$ & 12.17 & $0.15^{\mathrm{a}}$ \\
\hline & Twin & $3.19^{\mathrm{b}}$ & $8.49^{b}$ & $5.93^{\mathrm{a}}$ & 12.66 & $0.096^{\mathrm{b}}$ \\
\hline \multirow{4}{*}{$\begin{array}{l}\text { Interaction } \\
\text { sex } \times \text { birth type }\end{array}$} & male $\times$ single & $3.91^{\mathrm{a}}$ & $11.78^{\mathrm{a}}$ & $3.87^{\mathrm{b}}$ & $11.67^{\mathrm{b}}$ & $0.14^{\mathrm{b}}$ \\
\hline & male $\times$ twin & $3.14^{b}$ & $8.99^{\mathrm{b}}$ & $5.56^{\mathrm{a}}$ & $10.35^{\mathrm{b}}$ & $0.10^{\mathrm{c}}$ \\
\hline & female $\times$ single & $3.18^{b}$ & $12.60^{\mathrm{a}}$ & $3.36^{\mathrm{b}}$ & $12.67^{\mathrm{b}}$ & $0.17^{\mathrm{a}}$ \\
\hline & female $\times$ twin & $3.23^{\mathrm{b}}$ & $7.98^{\mathrm{b}}$ & $6.29^{\mathrm{a}}$ & $14.98^{\mathrm{a}}$ & $0.089^{\mathrm{c}}$ \\
\hline \multirow{4}{*}{$\begin{array}{l}\text { Interaction } \\
\text { sex } \times \text { birth season }\end{array}$} & male×rainy & $3.16^{\mathrm{b}}$ & 9.80 & 4.71 & - & 0.11 \\
\hline & female $\times$ rainy & $3.22^{\mathrm{b}}$ & 10.08 & 4.51 & - & 0.12 \\
\hline & male $\times$ dry & $3.89^{\mathrm{a}}$ & 10.97 & 4.71 & - & 0.13 \\
\hline & female $\times$ dry & $3.19^{\mathrm{b}}$ & 10.50 & 5.14 & - & 0.13 \\
\hline
\end{tabular}

Means followed by different letters in the column differ statistically by Fisher's least significant difference test ( $\mathrm{p}<0.05$ ).

feed management, for example, a more intense use of a different ram to breed with ewes and an increase in the pasture area. For instance, the higher values for traits related to the performance until weaning in 2012 was probably due to the increase in the availability of food between the second and third quarters of 2011, after Tifton-85 (Cynodon dactylon) was grown in paddocks, and a protein bank of Leucaena leucocephala was made available for the sheep raised at the experiment location. As a result, there was an improvement in the nutritional levels of the ewes. Consequently, there was an improvement in the environment provided by the dams, which led to an increase in the weight of lambs at weaning. The significant increase in BW and TLWB between 2009 and 2010 may have been due to the higher number of births recorded in 2010 in comparison to 2009 (data not shown), or the more intense use of another ram to breed with ewes, as mentioned before. It is known that the paternal genotype clearly influences weight at birth in sheep (GARDNER et al., 2007) and, consequently, may influence weight gain until weaning.

There were no significant differences ( $p>0.05$ ) between the different birth seasons for any of the analyzed traits (Table 2). This may be due to the low humidity during the dry season in the region, which favors the reduction in the incidence of diseases and, consequently, contributes to improving the performance of ewes and lambs, provided that their nutritional requirements are met. Feed supplementation during the dry season may have also contributed to maintaining the nutritional level of dams and normal fetal development in pregnant ewes. Another possible explanation for the non-significant differences between birth seasons is that ewes that breed during the dry season usually give birth close to or during the rainy season in the region where this study was carried out. During the years of our experiment, approximately $70 \%$ of the births occurred 
during the rainy season (January to May, November, and December). In this period, there is greater feed availability and the pasture has a higher nutritional value, which improves the nutritional levels of the food provided to dams and their offspring.

No statistical differences $(p>0.05)$ were observed for the effect of dam age at lambing for BW and TLWB, whereas for the other traits, ewes that gave birth at two years old or less had mean values significantly lower than those of older dams (Table 2). Despite the non-significant differences in our results for BW and TLWB regarding the dam age at lambing, several authors have reported that younger ewes tend to give birth to lighter offspring, whereas older ewes give birth to heavier lambs (e.g., MOHAMMADI et al., 2012; KORITIAKI et al., 2013; PETTIGREW et al., 2019). According to WU et al. (2006), maternal maturity is one of the major factors that regulate placental growth and the transfer of nutrients from mother to fetus, which results in higher offspring birth weights. KORITIAKI et al. (2013) reported higher birth weights in Santa Inês lambs born from older dams $(4.23 \pm 0.19 \mathrm{~kg})$ in comparison to individuals born to younger ewes $(2.93 \pm 0.27 \mathrm{~kg})$ as well.

The significantly lower $(\mathrm{p}<0.05) \mathrm{WW}$, TLWW, and ADGBW values observed when considering the effect of dams that gave birth at two years old or less demonstrated that ewes older than two years had better maternal ability (Table 2). These results corroborate those of MOHAMMADI et al. (2012), who reported poor performance for maternal traits, including the development of lambs from birth until weaning, in two-year-old ewes of the Makooei breed. In the study mentioned above, the authors also observed a tendency for the productivity of ewes to improve with age, generally peaking between four and seven years of age. In some mammals, the influence of dam age on maternal ability starts in the prenatal period and lasts until the postnatal period, due to the care and milk provided by the dam (SARMENTO et al., 2003).

The effect of dam weight at lambing was significant $(\mathrm{p}<0.05)$ only for BW and TLWB (Table 2$)$, so that ewes weighing more than $40 \mathrm{~kg}$ gave birth to heavier offspring. These findings indicate that ewes with higher body weights give birth to heavier lambs, which is in agreement with the results reported on sheep by several authors (e.g., FERNANDES et al., 2001; GARDNER et al., 2007; KORITIAKI et al. 2012, 2013; PETROVIĆ et al., 2015; PETTIGREW et al., 2019). As the weight of ewes at lambing is mostly related to their nutritional status during pregnancy, well-nourished females in the pre- and post-lambing periods tend to produce heavier and healthier lambs (KORITIAKI et al., 2013). Genetic correlations between dam weight and the lamb weight are usually positive, ranging from moderate to high, so that heavier lambs at birth may be obtained based on selection for heavier dams (VATANKHAH, 2013). Nevertheless, VATANKHAH (2013) highlights that more resources are needed to meet the requirements of heavier ewes. In addition, large-birth-weight lambs and their dams are susceptible to dystocia (SUPAKORN et al., 2013). Thus, birth weight must be monitored in order to achieve natural births and healthy lambs.

The effect of sex was significant $(\mathrm{p}<0.05)$ only for TLWW (Table 2). The mean value of the total weight of female lambs at weaning was significantly higher than that observed for male lambs. This can be explained by the fact that there were more data of ewe lambs $(n=41)$ than ram lambs $(n=38)$ for weaning weight, which resulted in more contribution of females for the total litter weight at weaning. In fact, there were more females than male lambs in the study (Table 3).

With exception of TLWW, the effect of birth type was significant $(\mathrm{p}<0.05)$ for all the other studied traits (Table 2). Single-born lambs had higher average daily gain and were heavier than twin-born lambs from birth until weaning. On the other hand, the total litter weight at birth of twins was higher than the mean value observed for singletons. Several authors have reported that the type of birth influences the lamb's performance, so that singleton lambs usually have better performance than multiple-born lambs (MOHAMMADI et al., 2010; KORITIAKI et al., 2013; YAVARIFARD et al., 2015; AGUIRRE et al., 2017). According to BARROS et al. (2005), the superiority of singleton lambs can be explained by the nonexistence of intrauterine competition or competition for food (maternal milk).

The interaction between sex and birth type was significant $(p<0.05)$ for all traits (Table 2$)$. The effect of this interaction demonstrated that singleborn male lambs had the highest BW, whereas twinborn female lambs had the highest TLWW, probably because most of the twin births were composed of only females or lambs of both sexes. Interestingly, the WW and TLWB values of male and female singleborn lambs did not differ significantly. The same was observed in both sexes for twin-born lambs. These results corroborate those of SARMENTO et al. (2006), who reported that sexual dimorphism was masked by the effect of birth type and resulted in similar growth of male and female Santa Inês 
Table 3 - Percentage of lambs of each sex according to birth season and birth type.

\begin{tabular}{|c|c|c|c|c|c|c|}
\hline \multirow[t]{2}{*}{ Sex } & & \multicolumn{2}{|c|}{ - } & \multicolumn{3}{|c|}{-------------------Birth type------------------- } \\
\hline & $\mathrm{N}$ & Rainy (\%) & Dry $(\%)$ & Single $(\%)$ & Twin $(\%)$ & Total $(\%)$ \\
\hline Male & 49 & 38.00 & 11.00 & 33.00 & 16.00 & 49.00 \\
\hline Female & 51 & 34.00 & 17.00 & 33.00 & 18.00 & 51.00 \\
\hline
\end{tabular}

$\mathrm{N}=$ sample size

lambs. In fact, the sexual hormones responsible for the dimorphism between the sexes have low activity in young animals and increase with age (KORITIAKI et al., 2013). In the present study, single-born female lambs had the highest ADGBW. This is probably due to the fact that singleton lambs had higher gains from birth until weaning, and because there were more female than male lambs.

The effect of the interaction between birth season and lamb sex was significant $(p<0.05)$ only for BW (Table 2). Male lambs born in the dry season were heavier than lambs of both sexes, regardless of the birth season. This can be explained by the fact that most of the singleton males were born during the dry season, which consequently increased the average BW of males due to the better sanitary conditions of the dry season, as mentioned above.

The correlation between lamb birth type and BW was low and negative (Table 4). However, the correlations of birth type with TLWB and TLWW and positive. These positive estimates can be attributed to twin births, which resulted in higher total litter weight at birth and, consequently, higher TLWW. These correlations corroborate the higher values of TLWB and TLWW associated with the effect of twin birth (Table 2). MOHAMMADI et al. (2012) reported positive estimates of genetic $(0.89 \pm 0.11)$ and phenotypic $(0.32 \pm 0.08)$ correlations between birth type and TLWB in Makooei sheep. In D'man sheep, BOUJENANE et al. (2013) also reported positive correlations between BT and TLWB, namely $0.74 \pm 0.12$ (genetic) and 0.77 (phenotypic). In both the studies mentioned above, the authors reported positive correlations between birth type and TLWW, as in the present study. On the other hand, the negative and moderate correlations of lamb birth type with WW and ADGBW reported here indicate that the individual performance of twin-born lambs from birth until weaning was poorer than that of singleborn lambs, which is in agreement with the literature (FERNANDES et al., 2001; GOOTWINE, 2005; SOUZA et al., 2014; PETTIGREW et al., 2019).

As expected, the correlation between BW and TLWB was positive (Table 4). Obviously, heavier birth weights result in heavier litter at birth and, consequently, the correlations of BW with TLWB are expected to always be positive and range from moderate to high magnitudes. The positive and moderate correlation observed between BW and WW was also expected, as the dams received supplemented feed during part of the pregnancy and the lambs had access to creep feeding before weaning. Many publications have reported moderate to high positive correlations between these two traits

Table 4 - Correlations between productive traits indicator of maternal ability and their correlations with lamb birth type in Santa Inês ewes.

\begin{tabular}{|c|c|c|c|c|c|}
\hline & BW & WW & TLWB & TLWW & ADGBW \\
\hline BT & $-0.10^{\mathrm{ns}}$ & $-0.49^{*}$ & $0.61^{*}$ & $0.19^{*}$ & $-0.49^{*}$ \\
\hline BW & & $0.48^{\text {ns }}$ & $0.60^{*}$ & $0.22^{*}$ & $0.20^{*}$ \\
\hline WW & & & $-0.08^{\mathrm{ns}}$ & $0.58^{*}$ & $0.96^{*}$ \\
\hline TLWB & & & & $0.55^{*}$ & $-0.26^{*}$ \\
\hline TLWW & & & & & $0.57^{*}$ \\
\hline
\end{tabular}

$\mathrm{BT}=$ lamb birth type; $\mathrm{BW}=$ birth weight; $\mathrm{WW}=$ weaning weight; TLWB $=$ total litter weight at birth; TLWW $=$ total litter weight at weaning; ADGBW = average daily gain from birth until weaning; ${ }^{*} \mathrm{P}<0.05$; ns = non-significant.

Ciência Rural, v.51, n.6, 2021. 
in different sheep breeds (HANFORD et al., 2003; BARROS et al., 2004; EL-AWADY, 2011; SAVARSOFLA et al., 2011; KAMJOO et al., 2014). In two studies that assessed the performance of purebred and crossbred Santa Inês lambs weaned at 70 days of age, KORITIAKI et al. (2012) reported a correlation of 0.43 between $\mathrm{BW}$ and WW, whereas KORITIAKI et al. (2013) found a correlation of 0.59 between the two traits mentioned above. According to SUPAKORN et al. (2013), the positive correlations between BW and WW are favorable and indicate that birth weight may be a candidate trait for growth improvement in sheep.

The positive correlations of BW with TLWW and ADGBW reported in the present study indicate that heavier lambs at birth tend to gain weight until weaning. According to EKIZ (2005), in mammalian species, growth traits, in particular until weaning, are substantially influenced by the environment provided by the dam.

The correlations of WW with TLWW and ADGBW were positive with moderate and high magnitudes, respectively (Table 4). These results were expected because lambs that present higher daily weight gains from birth until weaning will consequently be heavier at weaning. Some publications have reported correlations between WW and ADGBW above 0.90 in different sheep breeds (BOSSO et al., 2007; SAVAR-SOFLA et al., 2011; MOHAMMADI et al., 2015), including the Santa Inês breed (KORITIAKI et al., 2012, 2013). From an economic point of view, these correlations are interesting, as one of the main objectives of sheep meat producers is to obtain animals with a higher performance and a good weight for commercialization. Thus, optimizing lamb performance in the early stages of life can have a substantial impact on farm profitability.

A moderately positive correlation between TLWB and TLWW was found (Table 4). On the other hand, the correlations of TLWB with WW and ADGBW were low and negative. This probably indicates that lighter lambs at birth exhibited compensatory body weight gain until weaning. This compensatory gain can be explained by the maternal ability after lambing and may also have been influenced by the inclusion of solid feed in the creep feeding system before weaning during the experiment conducted in the present study. Similarly, MARTÍNEZ et al. (2015) reported that early creep feeding showed a positive effect on body weight gain and reduced the weight loss of Chilota breed lambs after the milk production peak of their dams.

The moderately positive correlation between TLWW and ADGBW (Table 4) indicates that the increase in individual average daily gain from birth until weaning is directly associated with the total litter weight at weaning. This can also be considered as an indicator of the influence of the dams on the performance of lambs from birth until weaning.

Genetic and phenotypic correlations are widely used to estimate the relationships among traits in different livestock species. However, these parameters require moderate or large sample sizes to generate more accurate estimates (KOMINAKIS, 2003). In the present study, a small sample size was used $(n=100)$, which is why we only calculated Pearson correlation coefficients. Thus, caution must be exercised when extrapolating the current results to other studies.

In this study, a total of $77.89 \%$ of the lambs born alive were weaned. As mentioned before, the number of weaned lambs may have been influenced by the greater care provided by the dams during the pre-weaning period. The percentage of weaned lambs in this study was higher than the overall rate reported by RIBEIRO et al. (2011) in the Brazilian context (62-64\%).

\section{CONCLUSION}

The maternal ability of Santa Inês ewes was more clearly influenced by the age and weight of the dam at lambing, and lamb birth type. In general, older dams weaned lambs with better performance, whereas heavier ewes gave birth to heavier lambs, and single-born lambs had the best individual performance from birth until weaning. It is important to focus on the nutrition and selection of ewes in order to obtain heavier lambs at birth. Furthermore, the environmental effects evaluated in this study should be included in models for genetic and phenotypic evaluation of maternal ability in Santa Inês sheep breeding programs to evaluate the influence of these effects on sheep raised in different conditions.

\section{ACKNOWLEDGEMENTS}

The authors thank the Conselho Nacional de Desenvolvimento Científico e Tecnológico $(\mathrm{CNPq})$, for the financial support in the execution of the research project and for granting a scholarship to the first author (grant 138521/2009-3), the Federal University of Piauí (UFPI), for the availability of animals and support for data collection, and the Coordenação de Aperfeiçoamento de Pessoal de Nível Superior (CAPES), Brasil Finance code 001

\section{BIOETHICS AND BIOSSECURITY COMMITTEE APPROVAL}

The research was carried out in accordance with the rules of the National Council for the Control of Animal 
Experimentation (CONCEA), as approved by the Ethics Committee on the Use of Animals (CEUA) of the Federal University of Piaui (protocol number 009/13).

\section{DECLARATION OF CONFLICTS OF INTERESTS}

The authors declare no conflict of interest. The founding sponsor had no role in the design of the study; in the collection, analyses, or interpretation of data; in the writing of the manuscript, and in the decision to publish the results.

\section{AUTHORS' CONTRIBUTIONS}

All authors contributed equally for the conception and writing of the manuscript. All authors critically revised the manuscript and approved the final version.

\section{REFERENCES}

AGUIRRE, E. L. et al. Genetic parameters and genetic trends for reproductive traits of Santa Ines sheep kept in extensive environments in Brazil. Journal of Animal Science and Livestock Production, v.1, n.2, p.1-7, 2017. Available from: <https://www. imedpub.com/animal-sciences-and-livestock-production/archive/ ipjaslp-volume-1-issue-2-year-2017.html>. Accessed: Mar. 15, 2020.

BAHREINI BEHZADI, M. et al. Estimates of genetic parameters for growth traits in Kermani sheep. Journal of Animal Breeding and Genetics, v.124, n.1, p.296-301, 2007. Available from: <https:// onlinelibrary.wiley.com/doi/abs/10.1111/j.1439-0388.2007.00672. $\mathrm{x}>$. Accessed: Aug. 26, 2020. doi: https://doi.org/10.1111/j.14390388.2007.00672.x.

BARROS, N. N. et al. Growth traits of slaughter F1 lambs in northeast of Brazil. Pesquisa Agropecuária Brasileira, v.39, n.8, p.809-814, 2004. Available from: <https://ainfo.cnptia.embrapa.br/ digital/bitstream/CNPC/17980/1/39n08a12.pdf > . Accessed: May, 28, 2011.

BARROS, N. N. et al. Bioeconomic efficiency of F1 Dorper x Santa Inês lambs for meat production. Pesquisa Agropecuária Brasileira, v.40, n.8, p.825-831, 2005. Available from: <https://www.scielo. br/scielo.php?pid $=$ S0100-204X2005000800014\& script $=$ sci arttext\&tlng=pt $>$. Accessed: Nov. 25, 2011. doi: 10.1590/S0100204X2005000800014.

BOSSO, N. A. et al. Genetic and phenotypic parameters of body weight in West African Dwarf goat and Djallonke sheep. Small Ruminant Research. v.67, n.2-3, p.271-278, 2007. Available from: <https://www.sciencedirect.com/science/article/abs/pii/ S0921448805004682>. Accessed: Dec. 13, 2011. doi: 10.1016/j. smallrumres.2005.11.001.

BOUJENANE, I. et al. Estimation of genetic parameters and genetic gains for reproductive traits and body weight of D'man ewes. Small Ruminant Research, v.113, n.1, p.40-46, 2013. Available from: <https://www.sciencedirect.com/science/article/ abs/pii/S0921448813000795?via\%3Dihub>. Accessed: Apr. 17, 2020. doi: 10.1016/j.smallrumres.2013.02.009.

CLOETE, S. W. P. et al. Genetic parameters and trends for lamb survival and birth weight in a Merino flock divergently selected for multiple rearing ability. Journal of Animal Science, v.87, n.7, p.2196-2208, 2009. Available from: <https://academic.oup.com/ jas/article/87/7/2196/4731070>. Accessed: Aug. 27, 2020. doi: $10.2527 /$ jas.2008-1065.

COSTA, D. S.et al. Growth rate of Santa Inês and F1 Dorper Santa Inês in natural pasture. Revista Brasileira de Saúde Produção Animal, v.13, n.1, p.237-243, 2012. Available from: <https:// www.scielo.br/scielo.php?script $=$ sci abstract\&pid $=\mathrm{S} 1519$ 99402012000100021\&lng=en\&nrm=iso\&tlng=pt $>$. Accessed: Apr. 23, 2020. doi: 10.1590/S1519-99402012000100021.

DWYER, C. M. Maternal behavior and lamb survival: from neuroendocrinology to practical application. Animal, v.8, n.1, p.102-112, 2014. Available from: $<$ https://www.cambridge.org/core/journals/animal/issue/ A4C69C02200507AAECA51ED935030D7B>. Accessed: Apr. 22, 2020. doi: https://doi.org/10.1017/S1751731113001614.

EKIZ, B. Estimates of maternal effects for pre and postweaning daily gain in Turkish Merino lambs. Turkish Journal of Veterinary and Animal Sciences, v.29, p.399-407, 2005. Available from: $<$ http://journals.tubitak.gov.tr/veterinary/abstract. $\mathrm{htm}$;jsessionid=AAD232A8296416EFD629FB8BD43F2BC4? id $=7564>$. Accessed: Dec. 15, 2011.

EL-AWADY, H. G. Different animal models for estimating genetic parameters of Barki sheep in Egypt. Journal of American Science, v.7, n.9, p.882-887, 2011. Available from: <https:// www.semanticscholar.org/paper/Different-Animal-Models-forEstimating-Genetic-of-El-Awady/b83167a0d3c9b240b3f86e0fd57 b607187a054a0\#citing-papers>. Accessed: Mar. 20, 2012.

FAO - Food and Agriculture Organization of the United Nations. Meat Market Review. Rome, 2019. Available from: $<$ http://www. fao.org/3/ca3880en/ca3880en.pdf $>$. Accessed: May, 18, 2020.

FERNANDES,A.A. O. etal. Environmental effects on growth rate of Morada Nova hair lambs in northeastern Brazil. Revista Brasileira de Zootecnia, v.30, n.5, p.1460-1465, 2001. Available from $<\mathrm{http} / / / \mathrm{www}$.scielo.br/scielo.php?script $=$ sci arttext\&pid=S151635982001000600012\&lng=en\&nrm=iso $>$. Accessed: Aug. 19, 2020. doi: $10.1590 / \mathrm{S} 1516-35982001000600012$.

FERNANDES, S.R. et al. Early weaning and concentrate supplementation on slaughter weight and carcass characteristics of lambs produced on pasture. Revista Brasileira de Saúde e Produção Animal, v.12, n.2, p.527-537, 2011. Available from: $\quad<$ http://revistas.ufba.br/index.php/rbspa/article/ viewArticle/1938>. Accessed: Aug. 27, 2020.

FREITAS, D. C. et al. Weaning age on feedlot hair sheep lambs performance in the northern litoral of Bahia. Revista Brasileira de Zootecnia, v.34, n.4, p.1392-1399, 2005. Available from: <https:// www.rbz.org.br/pt-br/article/idade-de-desmame-de-cordeirosdeslanados-para-terminacao-em-confinamento-no-litoral-norteda-bahia/>. Accessed: Apr. 24, 2020.

GARDNER, D. S. et al. Factors affecting birth weight in sheep: maternal environment. Reproduction, v.133, n.1, p.297-307, 2007. Available from: <https://rep.bioscientifica.com/view/ journals/rep/133/1/1330297.xml>. Accessed: Aug. 23, 2020. doi: 10.1530/REP-06-0042.

GOOTWINE, E. Variability in the rate of decline in birth weight as litter size increases in sheep. Animal Science,

Ciência Rural, v.51, n.6, 2021. 
v.81, n.3, p.393-398, 2005. Available from: <https:// www.cambridge.org/core/journals/animal-science/issue/ D0896AA6ABF849F580A24A343F7377CA>. Accessed: Aug. 17, 2020. doi: 10.1079/ASC41160393.

GOWANE, G. R. et al. The role of maternal effects in sheep breeding: a review. Indian Journal of Small Ruminants, v.20, n.1, p.1-11, 2014. Available from: <http://indianjournals.com/ ijor.aspx?target=ijor:ijsr\&volume $=20 \&$ issue $=1 \&$ article $=001>$. Accessed: Mar. 18, 2020

HANFORD, K. J. et al. Estimates of genetic parameters and genetic change for reproduction, weight and wool characteristics of Targhee sheep. Journal of Animal Science, v.81, n.3, p.630 640 , 2003. Available from: <https://academic.oup.com/jas/ article-abstract $/ 81 / 3 / 630 / 4789908>$. Accessed: Dec. 13, 2011. doi: $10.2527 / 2003.813630 \mathrm{x}$

IBGE - Brazilian Institute of Geography and Statistics. Agriculture and Livestock Census: preliminary results, 2018. Available from: $<$ https://biblioteca.ibge.gov.br/visualizacao/periodicos/3093/ agro 2017 resultados preliminares.pdf $>$. Accessed: Mar. 18, 2019.

INMET - Brazilian National Institute of Meteorology. Annual historical data, 2020. Available from: <https://portal.inmet.gov. br/dadoshistoricos $>$. Accessed: Aug. 15, 2020.

KAMJOO, B. et al. Genetic parameter estimates for growth traits in Iran Black sheep. Journal of Applied Animal Research. v.42, n.1, p.79-88, 2014. Available from: <https://www.tandfonline. com/doi/full/10.1080/09712119.2013.822806>. Accessed: Apr. 28, 2020. doi: 10.1080/09712119.2013.822806.

KOMINAKIS, A. P. Phenotypic correlations as substitutes to genetic correlations in dairy sheep and goats. Journal of Animal Breeding and Genetics, v.120, n.4, p.269-281, 2003. Available from: <https://onlinelibrary.wiley.com/doi/abs/10.10 46/j.1439-0388.2003.00397.x>. Accessed: Apr. 27, 2020. doi 10.1046/j.1439-0388.2003.00397.x.

KORITIAKI, N. A. et al. Factors that affect the performance from birth to weaning on purebred and crossbred Santa Ines lambs Revista Brasileira de Saúde e Produção Animal, v.13, n.1, p.258-270, 2012. Available from: <http://revistas.ufba.br/index. php/rbspa/article/viewArticle/2220>. Accessed: Apr. 25, 2020. doi: 10.1590/S1519-99402012000100023.

KORITIAKI, N. A. et al. Effect of environmental factors on performance of purebred and crossbred Santa Inês lambs from birth to 154 days of age. Revista Brasileira de Zootecnia, v.42, n.2, p.87-94, 2013. Available from: <https://www.scielo. br/scielo.php?pid $=$ S1516-35982013000200002\& script $=$ sci abstract>. Accessed: Apr. 25, 2020. doi: 10.1590/S151635982013000200002 .

LÔBO, A. M. B. O. et al . Genetic parameters for growth, reproductive and maternal traits in a multibreed meat sheep population. Genetics and Molecular Biology, v.32, n.4, p.761-770, 2009. Available from: <http://www.scielo.br/scielo. php?script=sci arttext\&pid=S1415-47572009000400016\&lng $=$ en\&nrm=iso $>$. Accessed: Sep. 2, 2020. doi: 10.1590/S141547572009005000080 .

LÔBO, R. N. B. et al. Genetic (co) variance components for ratio of lamb weight to ewe metabolic weights as an indicator of ewe efficiency. Livestock Science, v.143, n.2-3, p.214-219, 2012. Available from: <https://www.sciencedirect.com/science/article/ pii/S1871141311003337>. Accessed: Apr. 11, 2020. doi: 10.1016/j. livsci.2011.09.014.

MARTÍNEZ, M. E. et al. Effect of early creep feeding in the performance of Chilota breed lambs. Journal of Livestock Science, v.6, n.11, p.56-64, 2015. Available from: <http:// livestockscience.in/wp-content/uploads/Mart\%C $3 \%$ ADnez-etal-2015_creep-feeding.pdf $>$. Accessed: Apr. 10, 2020.

MCMANUS, C. et al. Genetics and breeding of sheep in Brazil. Revista Brasileira de Zootecnia, v.39, p.236-246, 2010. Available from: $\quad<$ http://www.scielo.br/scielo.php?script=sci arttext\&pid $=$ S1 1516-35982010001300026\&lng $=$ en \&nrm $=$ iso $>$. Accessed: Sep. 2, 2020. doi: 10.1590/S1516-35982010001300026.

MEDEIROS, R. M. Köppen and Thornthwaite climate classification method applied to the municipality of Bom Jesus PI, Brazil. Brazilian Journal of Agroecology and Sustainability, v.1, n.2, p.1-19, 2019. Available from: <http://journals.ufrpe.br/ index.php/BJAS/article/view/2648>. Accessed: Aug. 24, 2020.

MOHAMMADI, H. et al. Genetic analysis of ewe productivity traits in Makooei sheep. Small Ruminant Research, v.107, n.2-3, p.105-110, 2012. Available from: <https://www.sciencedirect.com/ science/article/abs/pii/S0921448812001691>. Accessed: Apr. 17, 2020. doi: 10.1016/j.smallrumres.2012.04.019.

MOHAMMADI, K. et al. Investigation of environmental factors influence on pre-weaning growth traits in Zandi lambs. Journal of Animal and Veterinary Advances, v.9, n.6, p.1011-1014, 2010. Available from: <https://medwelljournals.com/abstract/?doi =javaa.2010.1011.1014>. Accessed: Dec. 14, 2011. doi: 10.3923/ javaa.2010.1011.1014.

MOHAMMADI, K. et al. Genetic parameter estimates for growth and reproductive traits in Lori sheep. Small Ruminant Research, v.131, p.35-42, 2015. Available from: $<\mathrm{https}: / / \mathrm{www}$. sciencedirect. com/science/article/abs/pii/S0921448815300341>. Accessed: Apr. 12, 2020. doi: 10.1016/j.smallrumres.2015.07.029.

MOREL, P. C. H. et al. Effects of birth weight on survival in twin born lambs. Proceedings of the New Zealand Society of Animal Production, v.69, p.75-79, 2009. Available from: <http://www. nzsap.org/proceedings/2009/effects-birth-weight-survival-twinborn-lambs>. Accessed: Aug. 26, 2020.

PERUZZI, A. Z. et al. Early weaning in Santa Ines lambs. Revista Agrarian, v.8, n.27, p.81-91, 2015. Available from: <http:// ojs.ufgd.edu.br/index.php/agrarian/article/view/2880/2181>. Accessed: Mar. 21, 2020.

PETROVIĆ, M. P. et al. Effect of genetic and environmental factors on the phenotype characteristics of lambs. Biotechnology in Animal Husbandry, v.31, n.2, p.223-233, 2015. Available from: $\quad<\mathrm{http} / /$ www.doiserbia.nb.rs/Article.aspx?ID=145091561502223P\#.X3OPr2hKjIU>. Accessed: Aug. 10, 2020. doi: https://doi.org/10.2298/BAH1502223P.

PETTIGREW, E. J. et al. The effects of birth rank (single or twin) and dam age on the lifetime productive performance of female dual purpose sheep (Ovis aries) offspring in New Zealand. PLoS One, v.14, n.3, e0214021, 2019. Available from: <https://journals. plos.org/plosone/article?id=10.1371/journal. pone. $0214021>$. Accessed: Aug. 15, 2020. doi: 10.1371/journal.pone.0214021. 
RIBEIRO, L. A. O. et al. Sheep management during tupping and lambing time: new techniques to reduce reproductive losses. Revista Brasileira de Reprodução Animal, v.35, n.2, p.171-174, 2011. Available from: <http://www.cbra.org.br/pages/publicacoes/ rbra/v35n2/RB367\%20Ribeiro\%20pag171-174.pdf>. Accessed: Jan. 19, 2012.

ROSATI, A. et al. Genetic parameters of reproductive traits in sheep. Small Ruminant Research, v.43, p.65-74, 2002. Available from: <https://www.sciencedirect.com/science/article/abs/pii/ S0921448801002565>. Accessed: Dec. 11, 2011. doi: https://doi. org/10.1016/S0921-4488(01)00256-5.

SARMENTO, J. L. R. et al. Genetic and environmental effects on Nellore cattle growth in Paraiba. Revista Brasileira de Zootecnia. v.32, n.2, p.325-330, 2003. Available from: <https:// www.scielo.br/scielo.php? script $=$ sci_arttext\&pid $=S 1516$ 35982003000200010\&lng=pt\&tlng=pt $>$. Accessed: Dec. 21, 2011. doi: 10.1590/S1516-35982003000200010.

SARMENTO, J. L. R. et al. Analysis of the growth curve of Santa Ines sheep. Revista Brasileira de Zootecnia, v.35, n.2, p.435-442, 2006. Available from: <https://www.scielo. br/scielo.php?pid=S1516-35982006000200014\&script $=$ sci abstract\&tlng=pt $>$. Accessed: Dec. 20, 2011. doi: 10.1590/S151635982006000200014 .

SARMENTO, J. L. R. et al. Maternal effect or growth curve of Santa Inês sheep by random regression models. Comunicata Scientiae, v.2, p.113-121, 2011. Available from: <https://ainfo. cnptia.embrapa.br/digital/bitstream/item/42790/1/API-Efeitomaterno.pdf $>$. Accessed: Jan. 19, 2012.

SAVAR-SOFLA, S. et al. Investigation on direct and maternal effects on growth traits and the Kleiber ratio in Moghani sheep. World Applied Sciences Journal, v.14, n.9, p.1313-1319, 2011. Available from: <https:/www.idosi.org/wasj/wasj14(9)11/9.pdf>. Accessed: Feb. 04, 2012.

SNOWDER, G. D. Genetic improvement of overall reproductive success in sheep: A review. Archivos Latinoamericanos de Producción Animal, v.16, n.1, p.32-40, 2008. Available from: <http://www.bioline.org.br/ pdf?la08007>. Accessed: Aug. 24, 2020.

SOUZA, A. J. et al. Weight gain evaluation in Santa Inês lambs in the periparturition proceeding of Brazilian Central tableland. PUBVET, v.8, n.7, 1698, 2014. Available from: < https://www. pubvet.com.br/uploads/ee9836501daacbfb1 ca2e18f9600df95. pdf $>$. Accessed: Aug. 16, 2020.

SUPAKORN, C. et al. Estimation of genetic parameters and genetic trends for weight and body measurements at birth in sheep populations in Thailand. Sonklanakarin Journal of Science and Technology, v.35, n.1, p.1-10, 2013. Available from: <http://rdo.psu.ac.th/sjstweb/journal/35-1/35-1-1-10. pdf $>$. Accessed: Apr. 24, 2020.

VATANKHAH, M. Genetic analysis of ewe body weight in LoriBakhtiari sheep using random regression models. Journal of Livestock Science and Technologies, v.1, n.1, p.44-49, 2013. Available from: <https://lst.uk.ac.ir/article_480.html >. Accessed: Mar. 24, 2020. doi: 10.22103/jlst.2013.480.

WU, G. et al. Board-invited review: Intrauterine growth retardation: Implications for the animal sciences. Journal of Animal Science, v.84, n.9, p.2316-2337, 2006. Available from: <https://academic. oup.com/jas/article-abstract/84/9/2316/4777828?redirectedFrom= fulltext>. Accessed: Feb. 20, 2012. doi: 10.2527/jas.2006-156.

YAVARIFARD, R. et al. Estimation of genetic parameters for reproductive traits in Mehraban sheep. Czech Journal of Animal Science, v.60, n.6, p.281-288, 2015. Available from: <https:// www.agriculturejournals.cz/web/cjas.htm? volume $=60 \&$ firstPag $\mathrm{e}=281$ \& type $=$ publishedArticle $>$. Accessed: Apr. 12, 2020. doi: 10.17221/8242-CJAS.

ZUNDT, M. et al. Production and carcass characteristic of confined lambs born from Santa Inês ewes supplemented in different stages of pregnancy. Revista Brasileira de Zootecnia, v.35, n.3, p.928-935, 2006. Available from: <https://www.scielo. br/scielo.php?pid=S1516-35982006000300040\&script $=$ sci abstract\&tlng=pt $>$. Accessed: Dec. 12, 2011. doi: https://doi. org/10.1590/S1516-35982006000300040. 